\title{
Chemical defense of the Caribbean ascidian Didemnum conchyliatum
}

\author{
Hélène C. Vervoort ${ }^{1}$, Joseph R. Pawlik ${ }^{2, *}$, William Fenical ${ }^{1}$ \\ ${ }^{1}$ University of California, San Diego, Scripps Institution of Oceanography, La Jolla, California 92093-0236, USA \\ ${ }^{2}$ Biological Sciences and Center for Marine Science Research, University of North Carolina at Wilmington, Wilmington, \\ North Carolina, 28403-3297, USA
}

\begin{abstract}
Field and laboratory experiments were performed to investigate the palatability to predatory fishes of organic extracts of the Caribbean ascidian Didemnum conchyliatum. This tan-colored compound ascidian grows as an epibiont on seagrass blades. A dichloromethane/methanol extract of the ascidian incorporated into carrageenan food strips at the same volumetric concentration as the extract occurred in the ascidian tissues deterred feeding of a natural assemblage of consumers in the same seagrass beds from which the ascidians were collected. Bioassay-directed fractionation of this extract revealed that the deterrent property was restricted to fractions containing novel indolemaleimide-imidazole alkaloids, didemnimides A to D. Laboratory assays of purified metabolites revealed that didemnimides $C$ and $D$ deterred feeding by a generalist predatory reef fish, but that didemnimides $A$ and $B$ were not deterrent. Only didemnimide $D$ deterred feeding in the fieldi neither didemnimide $C$ nor the fraction containing didemnimides $A$ and $B$ were deterrent when assayed in the natural environment of the ascidian. Antipredatory activity of the didemnimides was highly dependent on compound structure: only didemnimide $D$, which bears both a bromine on the indole ring and a methyl group on the imidazole ring, inhibited feeding in both laboratory and field assays. Didemnimide D deterred feeding at approximately $0.035 \mathrm{mg} \mathrm{ml}^{-1}$, and is among the most potent antipredatory chemical defenses described from tunicates to date.
\end{abstract}

KEY WORDS: Ascidian - Chemical defense - Caribbean · Predation - Structure-function relationship

\section{INTRODUCTION}

Marine invertebrates that lack physical protection may use alternative defensive strategies such as chemical defense. Many of the unusual secondary metabolites that have been isolated from soft-bodied marine invertebrates are proposed to function as agents that deter predation (reviews in Paul 1992, Pawlik 1993). Only recently have ecologically relevant field and laboratory experiments been designed to test this hypothesis, and our knowledge of the ecological roles of invertebrate secondary metabolites has increased rapidly over the last decade (e.g. Pawlik et al. 1987. Harvell et al. 1988, McClintock et al. 1994, Pennings et al, 1994).

-Addressee for correspondence. E-mail: pawlikj@uncwil.edu
Most studies of marine invertebrate chemical defenses have focused on species from tropical reef habitats, where predation by fishes is intense (Hixon 1983, Grigg et al. 1984, Huston 1985). Less well studied are the chemical defenses of invertebrates from tropical, shallow soft-sediment environments: seagrass beds and mangroves. These habitats, which are geographically much more expansive than coral reefs, are under the influence of many of the same consumer species of fishes, in addition to a set of distinct fish and invertebrate predators (Thayer et al. 1987, Blaber et al. 1992, Worthington et al. 1992, Connolly 1994). Soft-sediment environments serve as nursery grounds for juveniles of many fishes that move off-shore as they mature.

Among the fouling invertebrates of tropical softsediment environments are several genera of ascidians, especially of the Didemnidae (Por 1984) Benthic ascidians appear to suffer little predation by generalist 
predators (Millar 1971, Goodbody \& Gibson 1974, Stoecker 1980), although they are consumed by some predatory molluscs (Young 1986, Dalby 1989, McClintock et al. 1994). Although didemnid ascidians have calcitic spicules in their tissues, available evidence suggests that they do not function as a structural defense against fish predators (Lindquist et al. 1992). In addition, some ascidians possess acidic inclusions or high concentrations of heavy metals in their tissues (e.g. vanadium; Hawkins et al. 1980); these substances were thought to inhibit fouling or predation (e.g. Stoecker 1978), but subsequent investigations have disputed this assessment (Parry 1984, Davis \& Wright 1989).

In general, the tissues of ascidians are a rich source of alkaloids and amino acid-derived secondary metabolites (reviewed in Davidson 1993, Molinski 1993), although the ecological functions of these compounds are largely unknown. Only very few studies have been performed to examine the feeding deterrent properties of ascidian metabolites, with some evidence for chemical defenses of both larvae and adults (Young \& Bingham 1987, Paul et al, 1990, Davis 1991, McClintock et al. 1991, Lindquist et al. 1992)

For the present study, we assessed the chemical defenses of Didemnum conchyliatum, a tan-colored didemnid ascidian from shallow Caribbean soft-sediment environments. A large population of $D$. conchyliatum was found encrusting the blades of the seagrass Thalassia testudinum in shallow $(<3 \mathrm{~m})$ seagrass meadows between mangrove islands at Sweetings Cay, Grand Bahama Island, Bahamas. Evidence of predation on this conspicuous soft-bodied animal was not observed. Preliminary chemical analysis of the organic extract of $D$. conchyliatum indicated the presence of large amounts of relatively polar, orangeand yellow-colored, secondary metabolites. The great abundance of $D$. conchyliatum at this site provided sufficient material for the isolation and characterization of these compounds (Vervoort et al. 1997). At the same time, we addressed the following questions concerning the ecological functions of these metabolites: first, do these compounds function as chemical defenses against generalist predators? Second, is there a relationship between the structure of the metabolites and their function as a feeding deterrent?

\section{MATERIALS AND METHODS}

Ascidian collection. This study was largely completed during an expedition to the mangroves surrounding Grand Bahama Island, Bahamas, on board the research vessel 'Seward Johnson' in September 1994. Approximately $2100 \mathrm{ml}$ wet volume of the com- pound ascidian Didemnum conchyliatum was collected at 1 to $3 \mathrm{~m}$ depth from a seagrass meadow between mangrove islands at Sweetings Cay. The collection included many hundreds of colonies from a large area (approx. $0.25 \mathrm{~km}^{2}$ ). The ascidians were immediately extracted for ecological and chemical investigations.

Extraction and isolation. The volume of the collected ascidians was determined by displacement in methanol. The tissue was then fully extracted with methanol and twice with a 1:1 mixture of dichloromethane $\left(\mathrm{CH}_{2} \mathrm{Cl}_{2}\right)$ and methanol. The resulting extracts were combined and divided into aliquots, each from a known volume of ascidian tissue.

One aliquot of the crude extract of Didemnum conchyliatum was used to separate the constituent metabolites of the extract by partitioning them between solvents of different polarities. The crude extract was successively partitioned between water and isooctane, dichloromethane, ethyl acetate, and 2 -propanol. The resulting 5 partitions were subjected to aquarium assays (see below).

The isooctane, dichloromethane, and ethyl acetate partitions each had some feeding deterrent activity, and contained metabolites in common when subjected to silica gel thin-layer chromatography (TLC) on Merck plastic-backed plates impregnated with fluorescent indicator. These 3 partitions were combined for subsequent fractionation by vacuum flash chromatography on silica gel employing a 0 to $5 \%$ methanol in dichloromethane gradient. The least polar fractions yielded a mixture of hydrocarbons, which were combined into a single fraction designated I. The next more polar fractions contained bright yellow-colored compounds, later identified as didemnimides $C$ and D, which were combined into a single fraction designated II. The next more polar fractions contained bright orange-colored compounds, later identified as didemnimides $\mathrm{A}$ and $\mathrm{B}$, which were combined and designated III. The 2 most polar, colorless fractions were designated IV and V Volumetric portions of all 5 fractions were tested for feeding deterrence in aquarium assays and field assays (see below).

A portion of fraction II was further separated by reverse phase liquid chromatography on an open column with $30 \%$ water in methanol as eluent, followed by normal phase liquid chromatography on an open column with $5 \%$ methanol in dichloromethane as eluent. This procedure yielded the pure didemnimides $C$ and $D$, in order of decreasing polarity, and a remaining mixture of less polar compounds that were not further identified. Didemnimides $C$ and $D$ and the remaining mixture were tested separately for feeding deterrence in aquarium assays and were used in field assays.

Structural assignments of secondary metabolites. A portion of fraction III was further separated by reverse 
phase liquid chromatography on an open column with $35 \%$ water in methanol as eluent, followed by normal phase liquid chromatography on an open column with $5 \%$ methanol in dichloromethane as eluent. This procedure yielded the pure didemnimides $A$ and $B$, in order of decreasing polarity. Didemnimide A was subjected to single crystal $X$-ray analysis to identify the carbon skeleton of the didemnimides (Vervoort et al. 1997). Didemnimides $A$ to $D$ were subsequently fully assigned using 1- and 2-dimensional NMR (nuclear magnetic resonance) spectroscopy, UV/VIS (UV and visible light) and infrared spectroscopy, and mass spectrometry (Vervoort et al. 1997).

Field assays. Feeding experiments were conducted in the field on each of 4 samples: the crude extract, purified didemnimide $\mathrm{C}$ and $\mathrm{D}$, and a combination containing fractions III, IV, $\mathrm{V}$, and the remains of fraction II after separation of didemnimides $C$ and $D$. In each case, the sample was volumetrically reconstituted in a matrix of carrageenan at the concentrations as they occurred in the ascidian. Strips of this matrix were then used in field experiments (see methods in Fenical \& Pawlik 1991). The matrix was made by combining 1.5 g carrageenan (Gelcarin, FF961L: FMC Corp, Philadelphia, PA, USA) and $3 \mathrm{~g}$ lyophilized, macerated squid with deionized water to a total volume of $65 \mathrm{ml}$. The mixture was heated to boiling in a microwave oven (about 1 min on 'cook'), then the sample, in a minimal volume of solvent (treated matrix) or solvent alone (control matrix), was added. The mixture was stirred and heated again to boiling (pure compounds were later judged to be stable to this treatment). The molten mixture was then poured into plastic molds crossed by lengths of cotton string that protruded from the ends of the molds. After the matrix cooled and gelled, $1.0 \times 0.5 \times 5.0 \mathrm{~cm}$ strips were sliced to size with a razor blade and removed from the mold. For each experiment, 20 treated strips and 20 control strips were prepared. To distinguish treated from control strips, the cotton string attached to each strip was marked with a small, colored ink spot.

Field assay methods are described in Pawlik \& Fenical (1989). One treatment and 1 control strip each were tied to a $50 \mathrm{~cm}$ length of 3-strand nylon rope at a distance of approximately 4 and $12 \mathrm{~cm}$ from one end of the rope (the order was haphazard). Twenty ropes were deployed in the same seagrass meadow from which the ascidians had been collected, with the end of each rope opposite the food strips attached to a large nail that was pushed into the sandy bottom. Ropes were left in the field for approximately $14 \mathrm{~h}$, overnight. After that time, the ropes were retrieved and the amount of each strip eaten was recorded as a percentage decrease in the strip length (to the nearest $5 \%$ ). The Wilcoxon paired-sample test (1-tailed; Zar 1984) was employed to analyze the results after excluding pairs for which both control and treatment slices had been either completely eaten, or not eaten at all.

Laboratory assays. Aquarium assays were performed as described in Pawlik et al. (1995) on the crude extract, each of the 5 solvent partitions, each of fractions I to $V$, purified didemnimides $C$ and $D$, and the remains of fraction II after separation of didemnimides $\mathrm{C}$ and D. Assays were performed on board the research vessel 'Seward Johnson' by employing a common predatory reef fish, the bluehead wrasse Thalassoma bifasciatum. The advantages of using this species for aquarium bioassays have previously been detailed (Pawlik et al. 1987, 1995). Groups of 3 fish (1 terminal phase male, 2 females) were held in each of 15 separate, opaque-sided compartments in flow-through laboratory aquaria. Groups of 10 fish were chosen out of 15 at random during feeding assays and randomly offered either a treated or control food pellet, followed by the other choice. When the second pellet was treated and was rejected, a third pellet was offered as a control to determine whether the fish had ceased feeding. Groups of fish that did not eat control pellets were considered satiated and were not used in the experiment. Pellets were considered rejected if not eaten after a minimum of 3 attempts, by 1 or more fish, to take them into their mouth cavity, or if the pellets were approached and ignored. The significance of differences in the consumption of treated versus control pellets was evaluated with the Fisher exact test (Zar 1984). For any single assay of 10 replicates, an extract was significantly deterrent if 4 or more of the pellets were rejected ( $\mathrm{p} \leq 0.043,1$-tailed test); therefore, a sample was considered deterrent if the number of pellets eaten was less than or equal to 6 .

Food pellets for laboratory assays were made by mixing a volume of $5 \mathrm{~g}$ lyophilized, macerated squid with $3 \mathrm{~g}$ alginic acid and $100 \mathrm{ml}$ water, followed by addition of the volumetric equivalent of a fraction or compound in a carrier solvent (for treated pellets) or solvent alone (for control pellets). The mixture was vigorously stirred to remove lumps and then loaded into a $5 \mathrm{ml}$ syringe. The tip of the syringe was then dipped into a beaker filled with a $0.25 \mathrm{M}$ solution of $\mathrm{CaCl}_{2}$ and the contents of the syringe slowly expelled to form a long strand. After a few minutes, the strand was removed, rinsed in seawater, and chopped into $4 \mathrm{~mm}$ long pieces with a razor blade to form uniform pellets.

\section{RESULTS}

Assay food strips containing a crude dichloromethane/ methanol extract of Didemnum conchyliatum at the same volumetric concentration as the extract occurs in 
the tissues of the ascidians significantly deterred feeding of a natural assemblage of consumers present in the seagrass bed ( $\mathrm{p}<0.0005$, Wilcoxon paired-sample test; Fig. 1). For this and for subsequent feeding assays, food strips were observed being consumed by clown and dwarf wrasse (Halichoeres maculipinna and Doratonotus megalepis, respectively) and bandtail pufferfish (Sphaeroides spengleri), although several. species of juvenile and adult parrotfishes and damselfishes were observed near the assay ropes.

In laboratory aquarium assays employing the reef fish Thalassoma bifasciatum the crude extract of Didemnum conchyliatum and the isooctane and dichloromethane partitions of the crude extract significantly deterred feeding (Fig. 2). The ethyl acetate partition did not significantly deter feeding, but TLC analysis revealed that this partition contained some of the same metabolites as the isooctane and dichloromethane partitions, albeit in lower concentrations. The 2-propanol and water partitions of the crude extract were distinct from the others by TLC, and did not deter feeding in aquarium assays (Fig. 2).

The combined isooctane, dichioromethane, and ethyl acetate partitions were further separated by vacuum flash chromatography into 5 fractions containing hydrocarbons (fraction I), didemnimides $\mathrm{C}$ and $\mathrm{D}$ (fraction II), didenmnimides $\mathrm{A}$ and $\mathrm{B}$ (fraction III), and more polar colorless compounds (fractions IV and V). Of these, fractions II and V significantly deterred feeding of Thalassoma bifasciatum in laboratory assays (Fig. 3).

Fraction II was further separated into 2 compounds, didemnimides $C$ and $D$, and a remaining mixture, by open column liquid chromatography. These were sub-

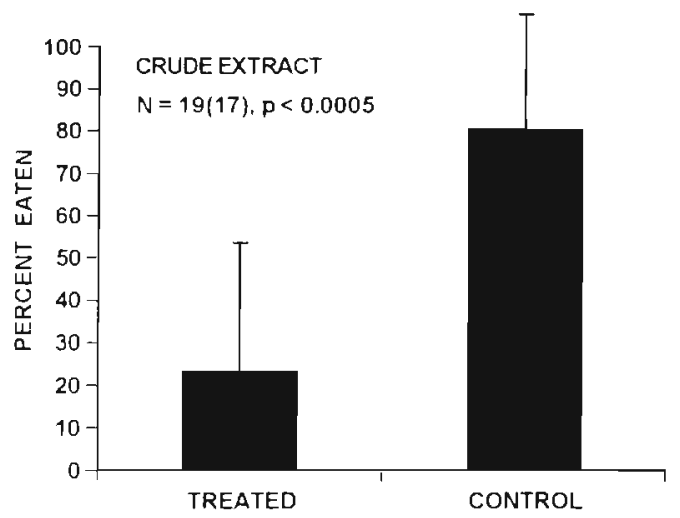

Fig. 1. Field assay. Feeding by seagrass bed consumers of paired control food strips and strips containing a crude extract. of Didemnum conchyliatum at the same concentration as found in the tissues of the ascidian. $1 \mathrm{SD}$ above the mean is indicated. N: no. of paired treatment and control strips retrieved of the 20 deployed (no of pairs used in statistical analysis). Probability calculated using the Wilcoxon pairedsample test

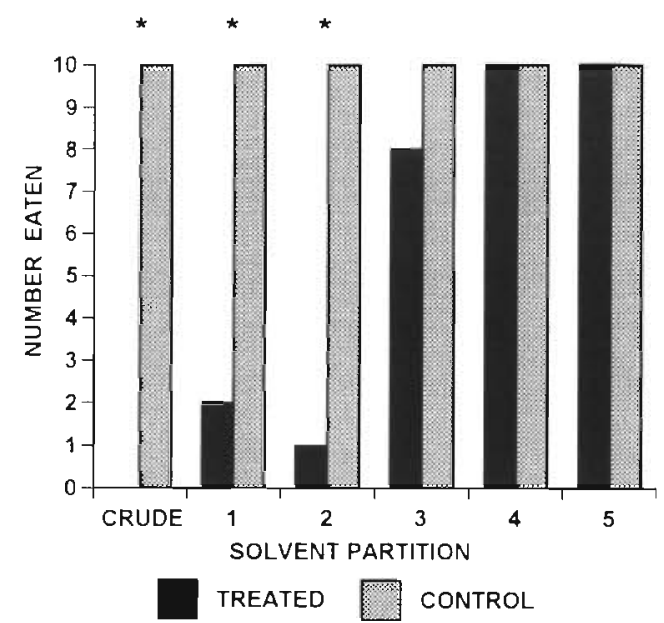

Fig. 2. Aquarium assay. Consumption by Thalassoma bifasciatum of control food pellets and pellets containing natural concentrations of the crucie exiraci and the soivent partitions $11=$ isooctane, 2 = dichloromethane, 3 = ethyl acetate, $4=2$-propanol, 5 = water) of the crude extract of Didemnum conchyliatum. ${ }^{*} p<0.05$, Fisher exact test

jected to laboratory assays at concentrations volumetrically equivalent to those found in the tissues of $D i$ demnum conchyliatum. Both didemnimides $C$ and D deterred feeding of Thalassoma bifasciatum, but the remaining mixture did not (Fig. 4)

Both didemnimides $C$ and $D$, and the remaining mixture of fraction II combined with fractions III, IV and V were all subjected to field assays in the seagrass meadows of the mangrove channel where the ascidians were collected. Although didemnimide D also deterred

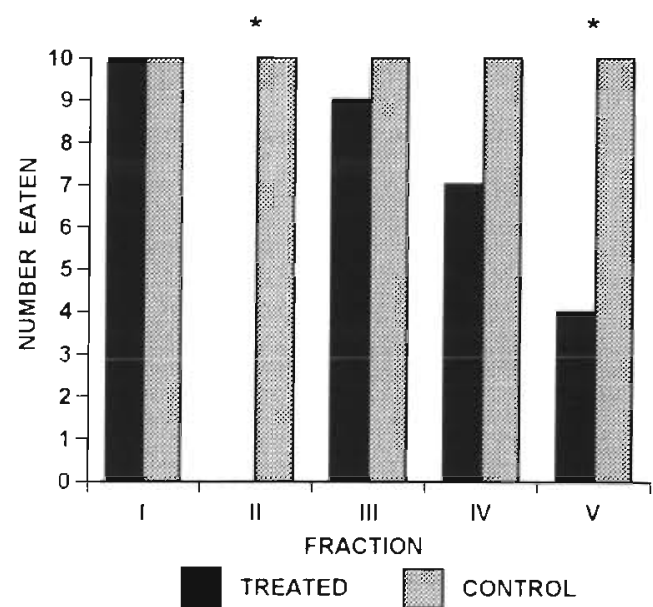

Fig. 3. Aquarium assay. Consumption by Thalassoma bifasciatum of control food pellets and pellets containing natural concentrations of fractions resulting from the flash column separation of the combined isooctane, dichloromethane and ethyl acetate fractions of the crude extract of Didemnum conchyliatum. ${ }^{*} p<0.05$, Fisher exact test 


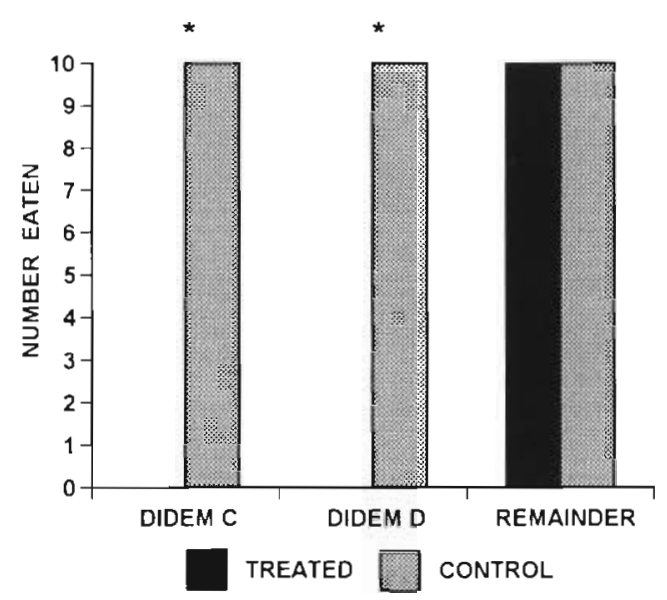

Fig. 4. Aquarium assay. Consumption by Thalassoma bifasciatum of control food pellets and pellets containing natural concentrations of purified didemnimides (didem) C, D, and the remaining mixture of fraction II (Fig. 3). ${ }^{*} \mathrm{p}<0.05$, Fisher exact test

feeding of a natural assemblage of mangrove consumers in field assays $(\mathrm{p}<0.0005$, Wilcoxon pairedsample test ${ }_{i}$ Fig. 5), didemnimide $C$ did not ( $p=0.81$; Fig. 6), and neither did the combination of fractions III, $I V, V$ and the remaining mixture of fraction II $(p=0.14$; Fig. 7).

Didemnimides A to D were reisolated and identified once the samples were brought back to the Scripps Institution of Oceanography (Fig. 8) (Vervoort et al. 1997). They are the first representatives of a novel class of indole-maleimide-imidazole alkaloids. The yellow didemnimides $C$ and $D$ were identified as methylated derivatives of the carbon skeleton. Didem-

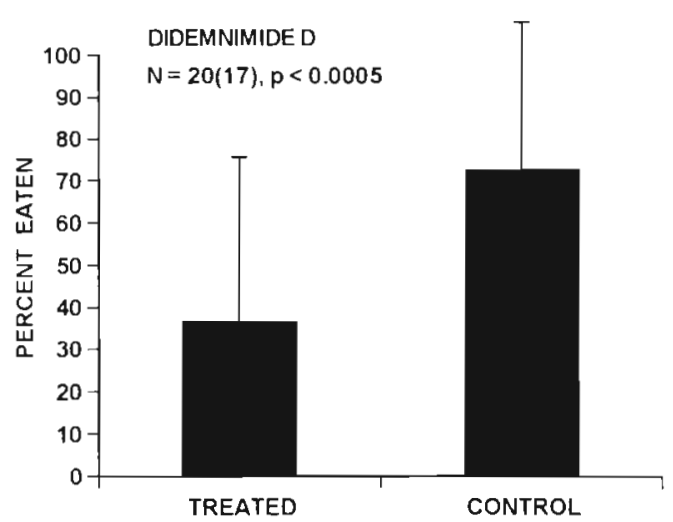

Fig. 5. Field assay. Feeding by seagrass bed consumers of paired control food strips and strips containing the natural concentration of didemnimide $\mathrm{D}$ isolated from fraction II (Fig. 3). $1 \mathrm{SD}$ above the mean is indicated. N: no. of paired treatment and control strips retrieved of the 20 deployed (no. of pairs used in statistical analysis). Probability calculated using the Wilcoxon paired-sample test

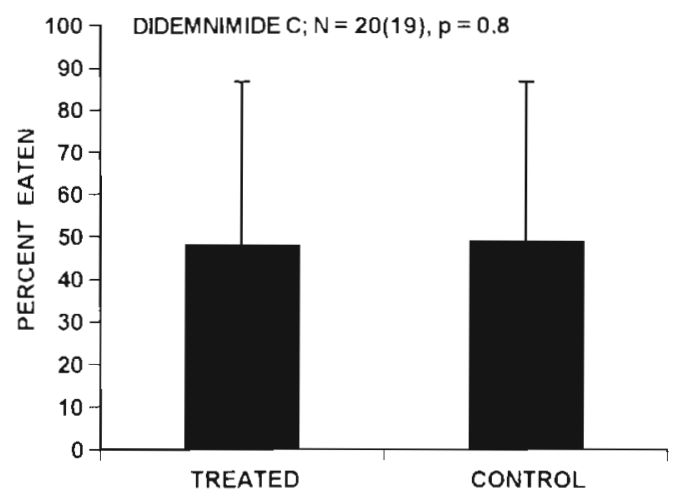

Fig. 6. Field assay. Feeding by seagrass bed consumers of paired control food strips and strips containing the natural concentration of didemnimide $\mathrm{C}$ isolated from fraction II (Fig. 3). 1 SD above the mean is indicated. N: no. of paired treatment and control strips retrieved of the 20 deployed (no. of pairs used in statistical analysis). Probability calculated using the Wilcoxon paired-sample test

nimide $D$, the less polar of the two, was found to be brominated. The more polar, orange didemnimides $A$ and $B$ were identified as non-methylated derivatives of this carbon skeleton. Didemnimide B, the less polar of the two, was brominated (Fig, 8).

Calculations of compound concentrations were all based on large collections of many hundreds of colonies of Didemnum conchyliatum because individual colonies were too small to be analyzed separately. As a mean value from 10 replicate samples, $100 \mathrm{ml}$ volume of ascidian tissue yielded $28.68 \mathrm{~g}$ of dry tissue and $2.68 \mathrm{~g}$ of crude organic extract. After solvent partitioning and liquid chromatography, the yields of pure

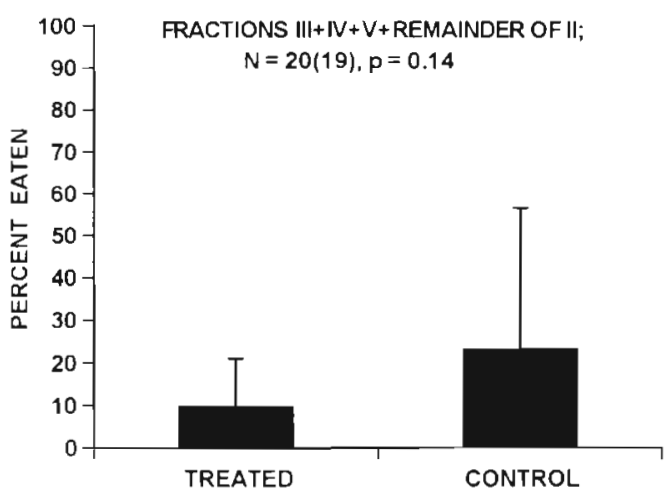

Fig. 7. Field assay. Feeding by seagrass bed consumers of paired control food strips and strips containing a combination of fractions III, IV, V (Fig. 2) and the remaining mixture of fraction II (Fig. 2) after separation of didemnimides C and D. $1 \mathrm{SD}$ above the mean is indicated. $\mathrm{N}$ : no. of paired treatment and control strips retrieved of the 20 deployed (no. of pairs used in statistical analysis). Probability calculated using the Wilcoxon paired-sample test 


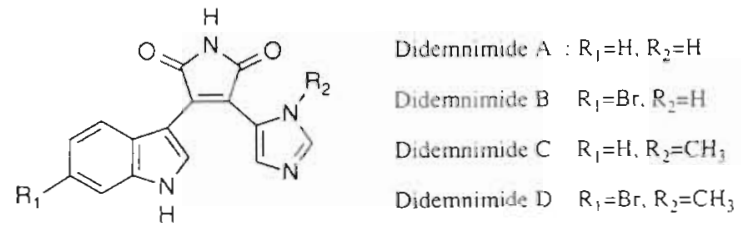

Fig. 8. Structures of didemnimides $A$ to $D$, as determined by crystal X-ray analysis, 2-dimensional NMR spectroscopy, UV/VIS and infrared spectroscopy, and mass spectrometry (Vervoort et al. 1997)

compounds from $100 \mathrm{ml}$ volume of ascidian tissue was estimated for didemnimides $A, B, C$, and $D$ to be 1.98 , $1.49,3.0$ and $3.5 \mathrm{mg}$, respectively.

\section{DISCUSSION}

The tissues of tropical ascidians continue to provide natural products chemists with unusual secondary metabolites of unknown ecological function (e.g.

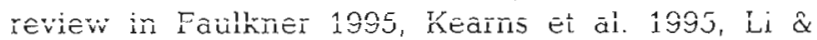
Blackman 1995). The present study is one of only a few to provide evidence of a defensive role for an identified secondary metabolite from an ascidian (Paul et al. 1990, Davis 1991, Lindquist et al. 1992, Lindquist \& Hay 1995). Like the present study, earlier investigators have found that unusual metabolites may or may not deter potential predators; in the latter case, these compounds may play other ecological roles. The tropical Pacific ascidian Sigillina signifera (= Atapazoa sp.) contains a series of bipyrrole metabolites, the tambjamines, some of which deterred feeding at or below natural concentrations in field assays conducted on Guam reefs (Paul et al. 1990). A prenyl hydroguinone from the temperate Pacific ascidian Aplidium californicum did not deter feeding when. assayed on Caribbean reefs at $0.25 \%$ dry weight; similarly, patellamide C from Lissoclinum patella did not deter predation on reefs in the Philippines (Lindquist et al. 1992). A Polyandrocarpa sp. from the Gulf of California contained a mixture of polyandrocarpidines, which deterred feeding of a hermit crab and 2 snail species (Lindquist et al. 1992). The Caribbean ascidian Trididemnum solidum and its tadpole larvae both contained a suite of didemnin and nordidemnin peptides, which inhibited feeding of reef fishes at concentrations below those found in the ascidian tissues. (Lindquist et al. 1992, Lindquist \& Hay 1995). A related species from the same area, Trididemnum cf. cyanophorum, contained a mixture of didemnenones that were not deterrent at natural concentrations (Lindquist et al. 1992).

The deterrent metabolite isolated from Didemnum conchyliatum in this study, didemnimide $\mathrm{D}$, is one of the most potent feeding deterrent metabolites isolated to date, with an active, natural concentration estimated at $0.035 \mathrm{mg} \mathrm{ml}^{-1}$. Among previously studied ascidian metabolites, didemnimide $D$ deters feeding at concentrations lower by an order of magnitude or more, rivaled only by the cyclic peptide nordidemnin B from another Caribbean didemnid. Trididemnum solidum (Lindquist et al. 1992). Although the active concentration of didemnimide $D$ is reported as the natural concentration in this paper, the value is likely a conservative one, because of loss of compound during the purification process. In point of fact, the crude extract of $D$. conchyliatum was more deterrent in both field and laboratory assays than subsequently purified fractions or compounds. This may result not only from a loss of active metabolites during purification steps but also from the separation of didemnimide $C$ from the mixture; the latter compound was deterrent in laboratory assays, but not field assays, at natural concentrations. Didemnimide $C$ may enhance the deterrent effects of didemnimide $\mathrm{D}$ in an additive or synergistic manner, resulting in the enhanced deterrent capacily of the crude extract. înevertheiess, didemnimide D is clearly the major deterrent compound in the crude extract, because field assays of both didemnimide $\mathrm{C}$ and the mixture containing fractions III to $\mathrm{V}$ were not deterrent (Figs. 6 \& 7).

It is possible that the contrasting tan pigmentation of colonies of Didemnum conchyliatum on green seagrass blades serves as aposematic or warning coloration. There is evidence that the orange color of larvae of the Caribbean ascidian Ecteinascidia turbinata deters predation by fishes that have previously sampled the distasteful larvae (Young \& Bingham 1987). Similarly, fish that sample and reject adult colonies of $D$. conchyliatum from seagrass blades may learn to avoid this potential food source. In a recent survey of the chemical defenses of Caribbean sponges, however, Pawlik et al. (1995) could find no relationship between coloration and chemical defense, suggesting that sponges are not aposematically colored and that color variation is the result of other factors.

Field assays conducted in earlier studies of invertebrate chemical defenses were performed on coral reefs over short periods of time $(<1 \mathrm{~h})$ during daylight hours (e.g. Pawlik \& Fenical 1992, Chanas \& Pawlik 1995), whereas the assays performed in the present study were conducted for $14 \mathrm{~h}$ or more, overnight. Assays strips left in seagrass beds for shorter periods of time during the day exhibited little evidence of feeding activity. Because the treatment and control food strips could not be observed during the preponderance of the nighttime assay period, the identities of the consumers is unknown, and may have included invertebrates. Bite marks on food strips, however, were identical to those 
we have seen in the past resulting from feeding by fishes, and it is presumed that the majority of feeding on food strips took place as fishes moved through the grassbeds during their crepuscular migrations (Jones et al. 1991).

A surprisingly large number of metabolites from marine invertebrates that have been subjected to relevant assays do not appear to play a role in antipredatory defense, and seemingly minor changes in stereochemistry. structure, or functionality of deterrent compounds renders them inactive (Pawlik 1993). Of the 4 didemnimides isolated from the tissues of Didemnum conchyliatum, only the fully substituted didemnimide $\mathrm{D}$, which bears both a bromine on the indole ring and a methyl group on the imidazole ring (Fig. 8), was deterrent in both laboratory and field feeding assays. While didemnimide $\mathrm{C}$ may also play a role in chemical defense (see earlier discussion), the functions of didemnimides $\mathrm{A}$ and $\mathrm{B}$ remains unresolved. One possibility is that these compounds are precursors of the more highly substituted didemnimides $C$ and $D$ and that the biosynthetic process of bromination and methylation requires an excess of precursor molecules to proceed. Alternatively, the biosynthetic pathway simply may not be optimized for the production of this chemical defense, and the inactive metabolites produced as side products may be regarded as so much 'biochemical baggage' (Haslam 1986). Finally, the possibility remains that didemnimides $\mathrm{A}$ and $\mathrm{B}$ function in some other role, defensive or otherwise, which might include antimicrobial, antifouling, or UV-protective (Pawlik 1993), but evidence of these possible functions awaits further experimentation.

Acknowledgements. This research is funded by the National Science Foundation, CHE93-22776 (to W.F.) and OCE9314145 (to J.R.P.), by the National Sea Grant College Program, National Oceanic and Atmospheric Administration, US Department of Commerce, under grant number NA89.1 A-DSG138, project number R/MP-54, through the Californin Sea Grant College (to W.F.). Our use of the research vessel 'Seward Johnson' was supported by the National Science Foundation, Chemıstry and Oceanography Divisions, under grant CHE90-08621 (to W.F.). We express our appreciation to Mr Colin Higgs, Ministry of Fisheries, Government of the Bahamas, for permission to perform research in their territorial waters.

\section{LITERATURE CITED}

Blaber SJM, Brewer DT, Salini JP, Kerr JD, Conacher C (1992) Species composition and biomasses of fishes in tropical seagrasses at Groote Eylandt, northern Australia. Estuar Coast Shelf Sci 35:605-620

Chanas B, Pawlik. JR (1995) Defenses of Caribbean sponges against predatory reef fish. II. Spicules, tissue toughness, and nutritional quality. Mar Ecol Prog Ser 127:195-211

Connolly RM (1994) Removal of seagrass canopy: effects on small fish and their prey. J Exp Mar Biol Ecol 184:99-110
Dalby JE Jr (1989) Predation of ascidians by Melongena corona (Neograstropoda melongenidae) in the northern Gulf of Mexico. Bull Mar Sci 45:708-712

Davidson BS (1993) Ascidians: producers of amino acid derived metabolites. Chem Rev 93:1771-1791.

Davis AR (1991) Alkaloids and ascidian chemical defense: evidence for the ecological role of natural products from Eudistoma olivaceum. Mar Biol 111:375-379

Davis AR, Wright AE (1989) Interspecific differences in fouling of two congeneric ascidans (Eudistoma olivaceum and E. capsulatum): is surface acidity an effective defense? Mar Biol 102:491-497

Faulkner DJ (1995) Marine natural products. Nat Prod Rep 12: $256-258$

Fenical W, Pawlik JR (1991) Defensive properties of secondary metabolites from the Caribbean gorgonian coral Erythropodium caribaeorum. Mar Ecol Prog Ser 75:1-8

Goodbody I, Gibson J (1974) The biology of Ascidia nigra (Savigny) V. Survival in populations settled at different times of the year. Biol Bull (Woods Hole) 146:217-237

Grigg RW, Polovina JJ, Atkinson MJ (1984) Model of a coral reef ecosystem. III. Resource limitation, community regulation, fisheries yield and resource management. Coral Reefs 3:23-27

Harvell CD, Fenical W, Greene DH (1988) Chemical and structural defenses of Caribbean gorgonians (Pseudopterogorgia spp.) I. Development of an in situ feeding assay. Mar Ecol Prog Ser 49:287-294

Haslam E (1986) Secondary metabolism-fact and fiction. Nat Prod Rep 3:217-249

Hawkins CH, Parry DL, Pierce C (1980) Chemistry of the blood of the ascidian Podoclavella moluccensis. Biol Bull (Woods Hole) 159:669-680

Hixon MA (1983) Fish grazing and community structure of coral reefs and algae: a synthesis of recent studies. In: Reaka MS (ed) The ecology of deep and shallow coral reeis. Symposia series for undersea research, NOAA/NURP, Washington, DC, p 79-87

Huston MA (1985) Patterns of species diversity on coral reefs. Annu Rev Ecol Syst 16:149-177

Jones GP, Ferrell DJ, Sale PF (1991) Fish predation and its impact on the invertebrates of coral reefs and adjacent sediments. In: Sale PF (ed) The ecology of fishes on coral reefs. Academic Press, New York, p 156-179

Kearns PS, Coll JC, Rideout JA (1995) A beta-carboline dimer from an ascidian, Didemnum sp. J Nat Prod (Lloydia) 58:1075-1076

Li C, Blackman AJ (1995) Cylindricines H-K, novel alkaloids form the ascidian Clavellina cylindrica. Aust J Chem 48 : 955-965

Lindquist N, Hay ME (1995) Can small rare prey be chemjcally defended? The case for marine larvae. Ecology 76 $1347-1358$

Lindquist N, Hay ME, Fenical W (1992) Defense of ascidians and their conspicuous larvae: adult vs. larval chemical defenses. Ecol Monogr 62:547-568

McClintock JB, Baker BJ, Slattery M, Hamann M, Kopitzke R, Heine J (1994) Chemotactic tube-foot responses of a spongivorous sea star Perknaster fuscus to organic extracts from Antarctic sponges. J Chem Ecol 20:859-870

McClintock JB, Heine J, Slattery M, Weston J (1991) Biochemical and energetic composition, population biology, and chemical defense of the Antarctic ascidian Cnemidocarpa verrucosa Lesson. J Exp Mar Biol Ecol 147. $163-175$

Millar RH (1971) The biology of ascidians. Adv Mar Biol 9:1-100

Molinski TF (1993) Marine pyridoacridine alkaloids: struc- 
ture, synthesis, and biological chemistry. Chem Rev 93: $1825-1838$

Parry DL (1984) Chemical properties of the test of ascidians in relation to predation. Mar Ecol Prog Ser 17:279-282

Paul VJ (1992) Ecological roles of marine natural products. Comstock Publishing Associates, Ithaca, NY

Paul VJ, Lindquist N, Fenical W (1990) Chemical defense of the tropical ascidian Atapazoa sp. and its nudibranch predators Nembrotha spp. Mar Ecol Prog Ser 59:109-118

Pawlik JR (1993) Marine invertebrate chemical defenses. Chem Rev 93:1911-1922

Pawlik JR, Burch MT, Fenical W (1987) Patterns of chemical defense among Caribbean gorgonian corals: a preliminary survey. J Exp Mar Biol Ecol 108:55-66

Pawlik JR, Chanas B, Toonen, RJ, Fenical W (1995) Defenses of Caribbean sponges against predatory reef fish. I. Chemical deterrency. Mar Ecol Prog Ser 127:183-194

Pawlik JR, Fenical W (1989) A re-evaluation of the ichthyodeterrent role of prostaglandins in the Caribbean gorgonian coral Plexaura homomalla. Mar Ecol Prog Ser 52:95-98

Pawlik JR, Fenical W (1992) Chemical defense of Pterogorgia anceps, a Caribbean gorgonian coral. Mar Ecol Prog Ser 97:183-188

Pennings SC, Pablo SR, Paul VJ, Duffy JE (1994) Effects of sponge secondary metabolites in different diets on feeding by three groups of consumers. J Exp Mar Biol Ecol 180:137-149

Editorial responsibility: Otto Kinne (Editor),

Oldendort/Luhe, Germany
Por FD (1984) The ecosystem of the mangal; general considerations. In: Por FD, Dor I (eds) Hydrobiology of the mangal. Junk Publishers, The Hague, p 1-14

Stoecker D (1978) Resistance of a tunicate to fouling. Biol Bull (Woods Hale) 155:615-626

Stoecker D (1980) Chemical defenses of ascidians against predators. Ecology 61:1327-1334

Thayer GW, Colby DR, Hettler WF (1987) Utilization of the red mangrove prop root habitat by fishes in South Florida Mar Ecol Prog Ser 35:25-38

Vervoort HC, Richards-Gross SE, Fenical W, Lee AY, Clardy J (1997) Didemnimides A-D: novel, predator-deterrent alkaloids from the Caribbean mangrove ascidian Didemnum conchyliatum. J Org Chem 62:1486-1490

Worthington DG, Ferrell DJ, McNeill SE, Bell JD (1992) Effects of shoot density of seagrass on fish and decapods: are correlations evident over larger spatial scales? Mar Biol 116:139-146

Young CM (1986) Defenses and refuges: alternative mechanisms of coexistence between predatory gastropod and its ascidian prey. Mar Biol 91:513-522

Young CM, Bingham BL (1987) Chemical defense and aposematic coloration in larvae of the ascidian Ectemascidia turbinata. Mar Biol 96:539-544

Zar JH (1984) Biostatistical analysis, 2nd edn. Prentice-Hall, Englewood Cliffs, NJ

Submitted: September 9, 1997; Accepted: December 16, 1997 proofs received from author(s): March 16, 1998 